\title{
Childhood Brain Neoplasm
}

National Cancer Institute

\section{Source}

National Cancer Institute. Childhood Brain Neoplasm. NCI Thesaurus. Code C7703.

A benign or malignant, primary or metastatic neoplasm of the brain occurring in children. 